Journal of Extension Education

Vol. 29 No. 4, 2017

DOI:https: / / doi.org/10.26725/JEE.2017.4.29.5972-5977

\title{
Capacity Development of Agricultural Stakeholders in Coimbatore district of Tamil Nadu - An Analytical Study
}

\author{
M. R. Naveen kumar ${ }^{1}$, P. Suganthkumar ${ }^{2}$, H. Philip ${ }^{3}$, \\ M. Asokhan ${ }^{4}$ and N. Sriram ${ }^{5}$
}

\begin{abstract}
This study was taken up to understand the training gaps and training needs of the agricultural stakeholders such as public, private extension officials and farmers in Tamil Nadu. The data were collected using pre tested well-structured questionnaire from public and private extension officials and using semi-structured interview schedule in case of farmers. The results show that training gaps are relatively higher among public extension officials than private extension officials. Demonstrations, group discussions, field visits, video lessons and SMS are the preferred training methods by the stakeholders.
\end{abstract}

Keywords : Capacity development; agricultural stakeholders; training gaps; training needs; Tamil Nadu

\section{INTRODUCTION}

Capacity development is dependent on the local context. Hence, no two stakeholders need the same capacity to prevail on. Stakeholders either are the group of people who gets affected in the positive or negative way by the decision whichever took in the organizational or institutional or at national level. For example., the agricultural stakeholders involves international organisations such as FAO, national organisations as Ministry of Agriculture and Farmers' welfare, several NGOs, Agricultural input manufacturers, suppliers, dealers, Public and private extension officials, farmers and their agents etc.,
In order to cope up with several contemporary transitions such as, shrinking per capita agricultural resources, changing farmer's and consumer needs, climate change, introduction of new technologies, changing preference of knowledge on social systems, information and communication technology tools' influence, gender mainstreaming etc., the capacity development among the agricultural stakeholders becomes inevitable.

In order to frame effective capacity development programmes an understanding of the capacity needs of

1. PhD scholar, 2. PG Scholar, 4. Professor \& Head, 5. Associate Professor, Dept. of Agricultural Extension and Rural Sociology and 3. Director of Extension Education, Tamil Nadu Agricultural University, Coimbatore - 641003. India 
the stakeholders are necessary for which the analytical study have been conducted among the three kinds of agricultural stakeholders, viz., public extension officials, private extension officials and farmers.

\section{METHODOLOGY}

The research design used was Ex-post facto. Simple random sampling procedure was followed to select the samples. The respondents were public extension officials such as, Agricultural officers, Assistant agricultural officers and Subject matter specialists of ATMA scheme; with regard to private extension officials, Marketing executives and Business managers were surveyed. Farmers belonging to Pasuvoor, AS Kulam, Maadhampatti, Chinavedampatti and Thondamuthur of Coimbatore district of Tamil Nadu were included. The sample size was 90 i.e., 30 samples per category. Data collection tools used were, pre tested well-structured questionnaire for public and private extension officials and semi-structured interview schedule in the case of farmers. Modes of data collection were, through personal interview, online mailing, social media and telephonic interview. The statistical tools used were percentage analysis and cumulative frequency.

\section{FINDINGS AND DISCUSSION}

Training gaps are denoted as, the vacuum that exists on already provided training components such as training interval, understanding level, interactiveness, approachableness and feedback obtainment of the trainers.

Table 1.

Distribution of Respondents based on Training Gaps

$(\mathrm{n}=60)$

\begin{tabular}{|c|l|c|c|c|c|}
\hline \multirow{2}{*}{$\begin{array}{c}\text { N1. } \\
\text { No. }\end{array}$} & Category & \multicolumn{2}{|c|}{$\begin{array}{c}\text { Government } \\
\text { officials }\end{array}$} & \multicolumn{2}{c|}{$\begin{array}{c}\text { Private } \\
\text { officials }\end{array}$} \\
\cline { 3 - 6 } & & No. & $\%$ & No. & $\%$ \\
\hline 1 & Low & 4 & 13.33 & 8 & 26.67 \\
\hline 2 & Medium & 12 & 40.00 & 8 & 26.67 \\
\hline 3 & High & 14 & 46.67 & 14 & 46.67 \\
\hline
\end{tabular}

The result shows that the training gap existence was more in terms of government extension officials than the private extension officials, as the government officials fell under the category of medium to high.

Training need refers to the focused area in which the respondents desired training. Data were collected on several sub variables such as training content for public and private extension officials and farmers, training venue for all three kinds of stakeholders, Training duration, Training period, Trainers and Training methods.

The sub variable 'training content' refers to the content or message of the training programme. Training venue denotes the places where the chosen agricultural stakeholders wish to undergo training. Training duration denotes 
the number of days the agricultural stakeholders would like to undergo per training. Training period denotes the season in which the trainees would like to attend the training. The 'trainers' refers to the qualified persons in specialized fields under whom the trainees are willing to attend the training and the Training methods relate to methods of training such as, Power Point lectures, group discussion, demonstrations, field visit, video lessons, SMS and Kisan voice calls.

Table 2 implies that both public and private extension officials have favoured technical training alone than the soft skills training and the combination of both technical and soft skill training.

Table 2.

Distribution of Respondents based on Training Skill for Officials

$(n=60)$

\begin{tabular}{|c|l|c|c|c|c|}
\hline \multirow{2}{*}{ S1. No. } & \multirow{2}{*}{ Cate gory } & \multicolumn{2}{|c|}{ Government officials } & \multicolumn{2}{c|}{ Private officials } \\
\cline { 3 - 6 } & & No. & $\%$ & No. & $\%$ \\
\hline 1 & Technical skills & 21 & 70.00 & 16 & 53.33 \\
\hline 2 & Soft skills & 5 & 16.67 & 11 & 36.67 \\
\hline 3 & Technical + Soft skills & 4 & 13.33 & 3 & 10.00 \\
\hline 4. & Total & 30 & 100.00 & 30 & 100.00 \\
\hline
\end{tabular}

*Multiple responses

Table 3.

Distribution of Respondents based on Training content for Farmers.

$(\mathrm{n}=30)$

\begin{tabular}{|l|l|c|c|}
\hline $\begin{array}{r}\text { S1. } \\
\text { No }\end{array}$ & \multicolumn{1}{|c|}{ Particulars } & Frequency* & Percentage \\
\hline 1. & Crop production and Protection & 21 & 70.00 \\
\hline 2. & Post-harvest technologies & 4 & 13.33 \\
\hline 3. & Marketing techniques & 19 & 63.33 \\
\hline 4. & Savings and Investment & 11 & 26.67 \\
\hline 5. & $\begin{array}{l}\text { Formation of Farmer groups and } \\
\text { associations }\end{array}$ & 36.67 \\
\hline
\end{tabular}

${ }^{*}$ Multiple responses 
Table 3 infers that farmer and protection aspects trainings respondents were showing much followed by marketing techniques. interest towards the crop production

Table 4.

Distribution of Respondents based on Training needs

$(\mathrm{n}=90)$

\begin{tabular}{|c|c|c|c|c|c|c|c|}
\hline \multirow[t]{2}{*}{ Particulars } & \multirow[t]{2}{*}{ Category } & \multicolumn{2}{|c|}{$\begin{array}{c}\text { Government } \\
\text { officials }\end{array}$} & \multicolumn{2}{|c|}{$\begin{array}{l}\text { Private } \\
\text { officials }\end{array}$} & \multicolumn{2}{|c|}{ Farmers } \\
\hline & & No. & $\%$ & No. & $\%$ & No. & $\%$ \\
\hline \multirow{5}{*}{$\begin{array}{l}\text { Training } \\
\text { Venue }\end{array}$} & Own village & 11 & 36.67 & & -- & 6 & 20.00 \\
\hline & Research Institutes & 5 & 16.67 & 10 & 33.33 & 4 & 13.33 \\
\hline & Agrl. Office & & -- & & -- & 2 & 6.67 \\
\hline & Success farmer fields & 14 & 46.66 & 5 & 16.67 & 18 & 60.00 \\
\hline & Star hotels & & -- & 15 & 50.00 & -- & -- \\
\hline \multirow{3}{*}{$\begin{array}{l}\text { Training } \\
\text { Duration }\end{array}$} & 1-3 days & 16 & 53.33 & 30 & 100.00 & 25 & 83.34 \\
\hline & 4-7 days & 8 & 26.67 & -- & -- & 5 & 16.66 \\
\hline & $>1$ week & 6 & 20.00 & -- & -- & -- & -- \\
\hline \multirow{4}{*}{$\begin{array}{l}\text { Training } \\
\text { period }\end{array}$} & Before cropping season & 16 & 53.33 & 27 & 90.00 & 11 & 36.67 \\
\hline & On cropping season & 6 & 20.00 & 3 & 10.00 & 13 & 43.33 \\
\hline & After problem arises & 4 & 13.33 & -- & -- & 4 & 13.33 \\
\hline & $\begin{array}{l}\text { Without affecting } \\
\text { routines }\end{array}$ & 4 & 13.33 & -- & -- & 2 & 6.67 \\
\hline \multirow{5}{*}{ Trainers } & $\begin{array}{l}\text { Academicians / } \\
\text { Scientists }\end{array}$ & 13 & 43.33 & 5 & 16.67 & 4 & 13.33 \\
\hline & Agri. dept. officials & 10 & 33.33 & 7 & 23.34 & 6 & 20.00 \\
\hline & Private officials & 5 & 16.67 & 16 & 53.33 & 3 & 10.00 \\
\hline & Progressive farmers & -- & -- & -- & -- & 17 & 56.67 \\
\hline & Bureaucrats & 2 & 6.67 & 2 & 6.67 & -- & -- \\
\hline
\end{tabular}




\begin{tabular}{|c|l|c|c|c|c|c|c|}
\hline \multirow{4}{*}{ Particulars } & \multicolumn{2}{|c|}{ Category } & \multicolumn{2}{c|}{$\begin{array}{c}\text { Government } \\
\text { officials }\end{array}$} & \multicolumn{2}{c|}{$\begin{array}{c}\text { Private } \\
\text { officials }\end{array}$} & \multicolumn{2}{c|}{ Farmers } \\
\cline { 3 - 9 } & & No. & $\%$ & No. & $\%$ & No. & $\%$ \\
\hline \multirow{4}{*}{$\begin{array}{c}\text { Training } \\
\text { methods }\end{array}$} & Power point lectures & 5 & 16.67 & 6 & 20.00 & 9 & 30.00 \\
\cline { 2 - 9 } & Group discussion & 17 & 56.67 & 16 & 53.33 & 19 & 63.33 \\
\cline { 2 - 9 } & Demonstrations & 23 & 76.67 & 13 & 43.33 & 30 & 100.00 \\
\cline { 2 - 9 } & Field visit & 19 & 63.33 & 8 & 26.67 & 18 & 60.00 \\
\cline { 2 - 9 } & Video lessons & 3 & 10.00 & 15 & 50.00 & 3 & 10.00 \\
\cline { 2 - 9 } & SMS & -- & -- & -- & -- & 27 & 90.00 \\
\cline { 2 - 9 } & KCC voice calls & -- & -- & -- & 17 & 56.67 \\
\hline
\end{tabular}

Table 4 indicates several phases of training needs. The public extension officials and farmers have shown interest towards attending trainings at the progressive farmer fields for better understanding of the clientele's mindset. Whereas, majority of private extension officials have shown interest towards attending trainings at the star hotel as it ensures conducive learning environment.

Irrespective of the classification, majority of the respondents have shown keen interest to attend the training of less than 3 days. This might be due to their fear of affecting their routines if the training prolonged more than 3 days.

In the case of training period, due to their busy working schedule, public and private extension officials were interested to attend the training before the start of the cropping season. However, majority of the farmers were interested to attend the training once the cropping season starts, the reason quoted by the farmers while inquiry was their lack of ability to retain the knowledge for longer time obtained through training.

When it comes to trainers, public extension officials were interested to be trained from the academicians and scientists. Private extension officials were interested to get trained from their own experienced senior colleagues. Farmers were interested to learn from their locally successful progressive farmers.

The training methods, which were desired by the majority of the public extension officials for their effective learning, demonstrations and field visits.

Private extension officials were interested towards learning through group discussion and video lessons. Whereas, farmers had shown interest towards learning through demonstrations 
and SMS, as they felt normal training which engages them completely for whole day as hectic; providing the information in simple local language and in several small parts in a regular basis shall help them in better retainment.

\section{CONCLUSION}

From the study, it could be concluded that majority of the farmers are in need of trainings related to crop production, protection and marketing aspects. They should be trained for less than three days by the onset of cropping season in the local progressive farmer fields by the progressive farmers using demonstration method. They should send regular SMSs for making the training programme effective. Majority of the public and private extension officials have favoured technical training alone. Public extension officials shall be trained for less than 3 days before the start of cropping season in the local progressive farmer fields by the academicians and scientists using demonstrations and field visits for making the training programme effective. In case of private extension officials, the training programme formulated for less than 3 days in the star hotels before the onset of cropping season by the senior private extension officials using group discussions and video lessons shall be effective.

\section{REFERENCES}

Mani, S. (1996). A Study on Training needs of Agricultural Officers under Tamil Nadu Agricultural Development Project. Unpublished M.Sc. Thesis. TNAU, Coimbatore. 